\title{
Facebook communities about nostalgic photos of Turkey: creative practices of remembering and representing the past
}

\section{Özlem Savaş}

To cite this article: Özlem Savaș (2017) Facebook communities about nostalgic photos of Turkey: creative practices of remembering and representing the past, Digital Creativity, 28:1, 48-57, DOI: 10.1080/14626268.2017.1291526

To link to this article: https://doi.org/10.1080/14626268.2017.1291526

曲 Published online: 20 Feb 2017.

Submit your article to this journal ¿

Џ Article views: 126

Q View related articles $\square$

View Crossmark data ¿ 


\title{
Facebook communities about nostalgic photos of Turkey: creative practices of remembering and representing the past
}

\author{
Özlem Savaş \\ Department of Communication and Design, Bilkent University, Ankara, Turkey
}

\begin{abstract}
This article focuses on Facebook communities about nostalgic photos of Turkey to explore how citizenship is enacted through the participatory and collaborative use of social media to remember and represent the past. By sharing their personal photos, knowledge, testimonies, narratives and life stories, members of these communities actively and creatively use social media to generate new ways of remembering and representing the past, as well as improving its accessibility and visibility. Furthermore, through exchanging affectively and politically charged photos and conversations about the past, participants fashion nostalgia as a public feeling that becomes a source for affective political criticism of the present. This article addresses the participatory and collaborative creation of knowledge and memory of the past to discuss everyday creative citizenship practices facilitated by social media.
\end{abstract}

\section{KEYWORDS}

Creative citizenship; memory; knowledge community; politics of nostalgia; social media

\section{Introduction}

The new and diverse forms of civic participation and action facilitated to a great extent by digital media technologies call into question the conventional understandings of citizenship and the public sphere. Broadened concepts of citizenship, such as 'cultural citizenship' (Miller 2006), 'creative citizenship' (Hargreaves and Hartley 2016) and 'DIY citizenship' (Ratto and Boler 2014), pay attention to productive digital media practices to locate new possibilities for enacting citizenship in the everyday. Hartley (2016) describes the creative, cultural or DIY approach to citizenship through the idea of citizens who 'create their own forms of "association among strangers" using the affordances of digital and interactive media, social networks, and their experiences and practices as audiences and consumers' (23).
The concept of creative citizenship attributes considerable civic value and effect to the everyday creative productions of individuals and communities in diverse domains, regardless of whether they have civic intent (Hargreaves 2016). Bourgeoning social media practices of self-presentation and community building have prompted critical attentiveness to productive citizens (Jenkins 2002; Uricchio 2004; Burgess, Foth, and Klaebe 2006; Hartley 2010). Ordinary participants in social media are recognized as active and productive agents who constantly move between modes of creating and using media content (Jenkins 2002; Bechmann and Lomborg 2013). Bruns (2008) coins the term 'produsage' to describe this hybrid form of producing and using knowledge in the participatory and collaborative social media 
environment. Specifically, the networked communities of interest and practice built by the active and creative contributions and sharing by their members (Uricchio 2004) constitute a 'connect-collaborate-create' model of DIY/ DIWO (Do-It-With-Others) citizenship practices (Hartley 2010). Collective, collaborative, and bottom-up creation and exchange are considered to have great potential to challenge conventional authorities of knowledge and expertise through the broadened understandings of citizenship, with critical attention to the limitations of the individuated, privatized and commercialized social media environment (Bruns 2008; Hartley 2010; Ratto and Boler 2014; Hargreaves and Hartley 2016).

This article focuses on Facebook communities that collect, share and archive nostalgic photos of Turkey to explore how citizenship is enacted and made sense of through the participatory and collaborative use of social media to remember and represent the past. Recently proliferating Facebook groups focusing around nostalgic images of Turkey digitally remediate old photos of people, places, activities, and events that are significant to personal and collective memories alike, and that are gathered from a wide range of sources, including family albums, private collections, archives, postcards, advertisements and popular magazines. A search in the category of groups with the keywords 'eski fotoğraflar' (old photos) and 'eski fotoğrafları' (old photos of) yielded 243 Facebook groups (as of 26 November 2016). While some groups centre on Turkey's past in general, others are dedicated to particular towns or topics. In this article, I focus on the Facebook groups Eski Türkiye Fotoğrafları-Old Photos of Turkey and Eski Türkiye Fotoğrafları-Photos of Old Ankara, which are among the oldest, most active and most popular groups about nostalgic photos of Turkey (respectively, 47,341 and 44,792 members as of 26 November 2016). In both groups, participants post several photos daily and 'like,' re-post and comment on each other's photos. Due to my own interest in nostalgic photos, I have been participating in both groups as a member for about seven months by posting 'likes' and comments on the photos.

What inspired me to think about creative citizenship practices in these two Facebook groups is the active participation of many diverse members, through exchanging not only their photos but also their personal knowledge, memories, testimonies, life stories and political views. Different from various other groups that collect and display nostalgic photos, participants in Old Photos of Turkey and Photos of Old Ankara engage in long discussions about the photos, yielding a particular kind of knowledge, memory and representation of the past. This participatory and collaborative memory work improves the past's visibility and fluidity of, as well as its accessibility. It also potentially yields a different kind of memory, one that calls into question the conventionalized, authoritative and institutionalized expertise about history (Haskins 2007; Garde-Hansen, Hoskins, and Reading 2009; Hoskins 2009). Furthermore, transcending personal interest in nostalgic images, participants in these communities assume responsibility for preserving, displaying and defending the past, which is reinforced by an everyday politics of nostalgia. Participants shape and engage in a 'cultural public sphere,' which 'refers to the articulation of politics, public and personal, as a contested terrain through affective (aesthetic and emotional) modes of communication' (McGuigan 2005, 427).

In this article, I draw on the remediation and exposure of personal photos (mostly from family albums) that depict ordinary individuals and families posing in homes, studios, streets and schools at celebrations, picnics, holidays and so on. Such a relocation of private memories into the cultural public sphere of social media perfectly epitomizes participatory and affective practices of remembering and representing the past. I discuss creative citizenship practices of the Facebook communities around nostalgic photos of Turkey, which entail a 
collaborative and participatory creation of knowledge and memory of the past and articulate an affective politics of nostalgia that criticizes the present.

\section{The collaborative memory and knowledge of the past}

The group description of Old Photos of Turkey opens with: 'Hello, lovers of Turkey, the aim of our group is to tell Turkey's past and to reinforce its beauty, character and history, thanks to the old photos.' With considerable attention to the archival value of its activities, the group organizes posted photos in separate albums that focus on diverse topics, including 'Family Albums' (Figure 1), 'Past Figures and Events,' 'Our History of War,' 'Politicians and The Political Past,' 'Panorama of Turkey's People,' 'Occupations,' 'Studio Photos,' 'School Years,' 'Musicians,' 'The World of Sports,' 'Nostalgic Transportations' and so on. Group members actively contribute to this archival work by posting their photos and leaving comments that aim to clarify the people, places, objects, activities and time periods portrayed.

Many photos posted to Old Photos of Turkey and Photos of Old Ankara prompt an enthusiastic and collaborative effort to provide information about historical details that are not explained by the captions, such as places, people and time periods; professions, arts and handcrafts; fabrics, styles and social meanings of clothing; tools, machines, guns and transportation modes; buildings, houses, schools and hospitals; cityscapes and landscapes; and customs, traditions, rituals, manners and words. Individual contributions to this collaboratively created and exchanged knowledge of the past reflect multiple and diverse ways of knowing (Jenkins 2002), such as personal interests and practices, professional expertise, and testimonies, biographies and life stories. For example, a photo of a family posing in front of a bus, posted on Old Photos of Turkey and stored in 'Family Albums' has an uninformative, candid caption, 'With my aunt and my mom,' and has sparked numerous explanatory comments (Figure 2): 'This photo is from the 1930s,' 'The bus is a 1930 Büssing-NAG,' 'This is the transit bus between Trabzon and Iran.' One comment states that the place in the photo is Trabzon (a northern city) because 'the writing on the bus is something like "state bus" and "Trabzon." Another comment opposes it by asserting: 'It cannot be Trabzon, based on the way people look.' The conversation continues with expressions of private memories and life stories that relate to the contents of the photo:

There was a transit route from Trabzon [to Iran]. My grandfather used to bring precious fabrics and carpets to my mother and grandmother. Back then, my grandparents had a mansion in Trabzon. People of Trabzon used to be chic like this; some are still chic.

Those were my secondary school years. The same type of bus used to transport people from Üsküdar [an Istanbul neighborhood] to Şile [another Istanbul district]. We took a school trip. Because it was very hot, the bus had its windows open. We were covered with dust and dirt. I still remember it.

Through the collaborative intellectual and emotional efforts to illuminate Turkey's past, Facebook groups about nostalgic photos of Turkey build knowledge communities, which Jenkins (2002) defines by drawing on the idea of Lévy's (1997) collective intelligence. Knowledge communities depend on the principle of a collective and reciprocal exchange of knowledge, which is essential to participatory culture, and potentially challenges traditional hierarchies of expertise. The knowledge these groups produce is accumulated as 'a "patchwork" woven together from many sources as members pool what they know, creating something much more powerful than the sum of its parts' (Jenkins 2002, 160). With respect to digitally mediated memory work, Haskins (2007) similarly argues that a collective and participatory authorship promises non-hierarchal, plural and vernacular representations of the past, 


\section{"ETF AiLE ALBÜMLERI ALBÜM 01"}
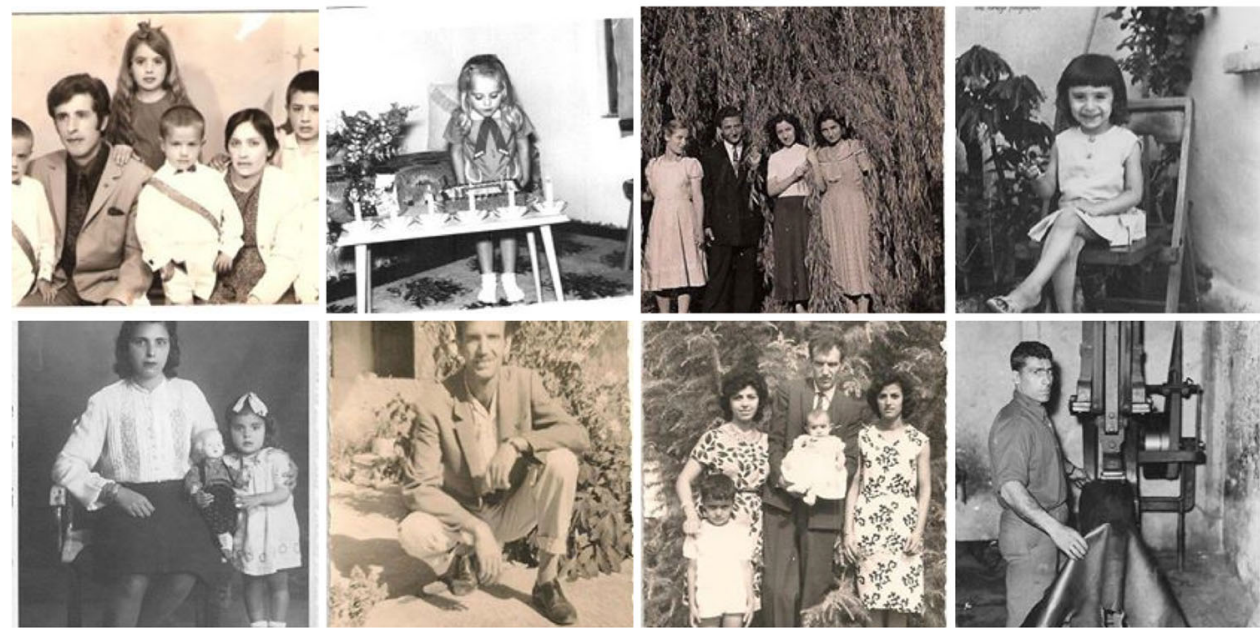

Figure 1. A screenshot of the album 'Family photos' stored in old photos of Turkey. With kind permission of old photos of Turkey.

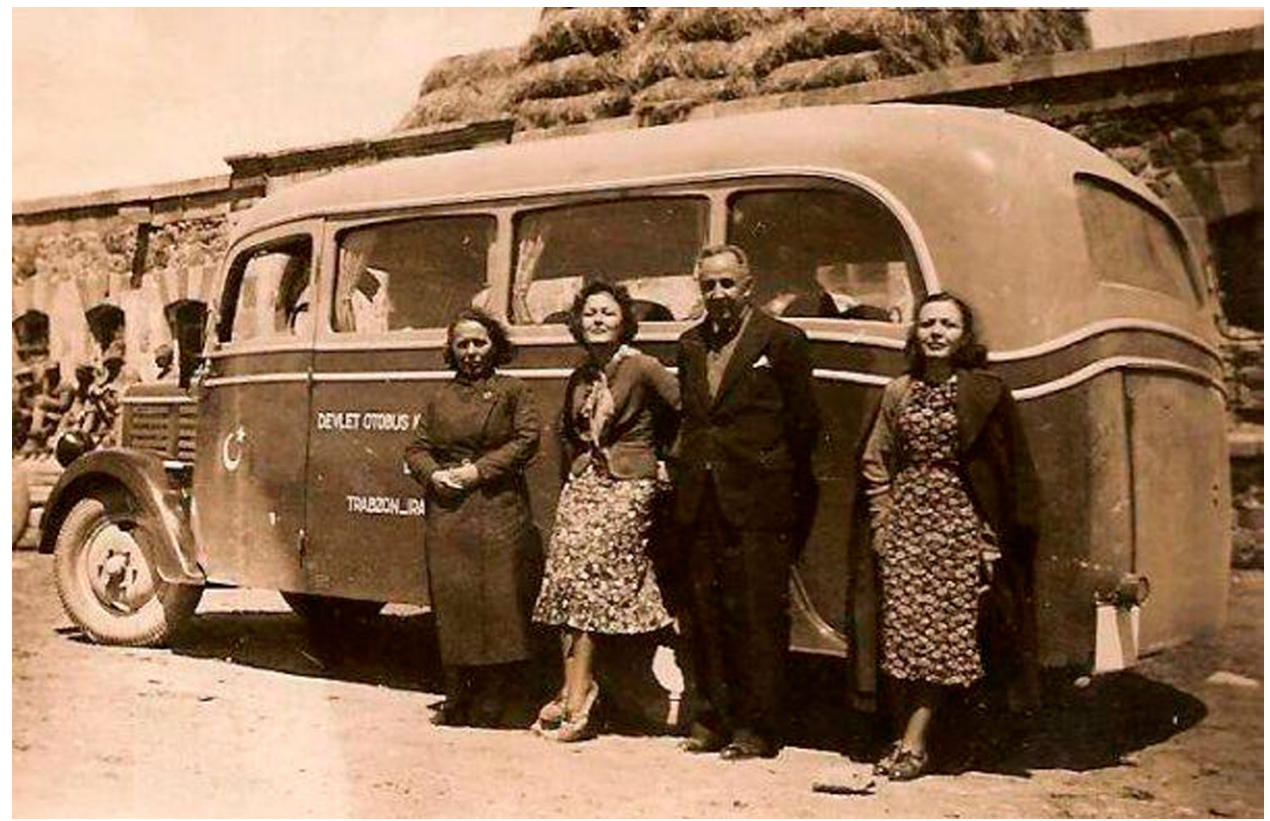

Figure 2. A family photo stored in 'Family Albums' in old photos of Turkey with the caption, 'With my aunt and my mom.' With kind permission of old photos of Turkey. 
and constitutes a significant alternative to the idealized and homogenized history that emerges from 'official institutions of remembrance' such as museums, archives, and memorials. $\mathrm{He}$ suggests:

At least in theory, online memorializing can accommodate an infinite variety of artifacts and performances.... Instead of only official accounts disseminated by mainstream media and the government, all kinds of stories can now become part of an evolving patchwork of public memory.... The boundaries between the official and the vernacular, the public and the private, the permanent and the evanescent will cease to matter, for all stories and images will be equally fit to represent and comment on the past. (Haskins 2007, 405)

The collaborative memory of Turkey created by the Facebook communities I studied reflects such a patchwork, composed of various images, knowledge and stories, and none emerges as more important or trivial than any other. Ordinary private photos and accompanying pieces of knowledge and life stories gathered from diverse sources create a different kind of memory, a 'social network memory,' which bridges the personal with the collective (Hoskins 2009). This vernacular knowledge and memory of the past challenge the authoritative and institutionalized expertise on history, not only because the 'patchworks' are created through the participation and collaboration of ordinary individuals, but also because they gather private, subjective and affective representations of the past.

\section{Affective politics nostalgia}

'Nothing is left now; only lovely memories.' Written under a photo of Ankara's oldest neighbourhood and posted to Photos of Old Ankara, this comment epitomizes the prevailing nostalgia, 'a yearning for a different time' (Boym 2007, 8 ) in Facebook groups about old photos. Many comments posted to Old Photos of Turkey and Photos of Old Ankara compare Turkey's past and present and suggest the decline of the latter. 'Those were the days' is commonly voiced both by group members with personal recollections of the past and by younger ones who imagine it. Old photos of places, people, events and various everyday scenes are regarded as visual evidence of the 'good old days,' when the life was remembered (or imagined) to be more peaceful, wholehearted and humane. More strikingly, nostalgic photos of Turkey are observed as a measure of modernity and civilization, perceived as achieved in the past but currently under threat of effacement. People of the past, especially women, are usually described as more beautiful, elegant, noble, classy, mannered, polite, civilized and modern. A family photo of a picnic, a studio photo of a woman and a photo of young women in a village near Ankara (Figure 3) posted on Photos of Old Ankara have prompted a large number of such comments:

Just compare the way of life back then with our present situation. The photo swells with civilization.

This photo is one in the eye for today's antimodern mindset.

Who knows how the grandchildren of these modern young girls look today?

It looks like it's the year 2050, and republic and modernity are back in the country.

In her study of vintage photographs of Egypt shared on Facebook groups, Ryzova (2014) very similarly observes that images of the past act as visual proof of a nostalgic imagination that suggests that civilization and modernization were achieved in the good old days. She argues that vintage photographs are stripped of their historical contexts and resignified in the new digital environment with new meanings that 'always stand for more than their referents' (Ryzova 2014, 309). In the Facebook groups of nostalgic photos of Turkey, resignification of personal photos as a measure of civilization and modernity is largely indebted to a pre-exist- 
(a)

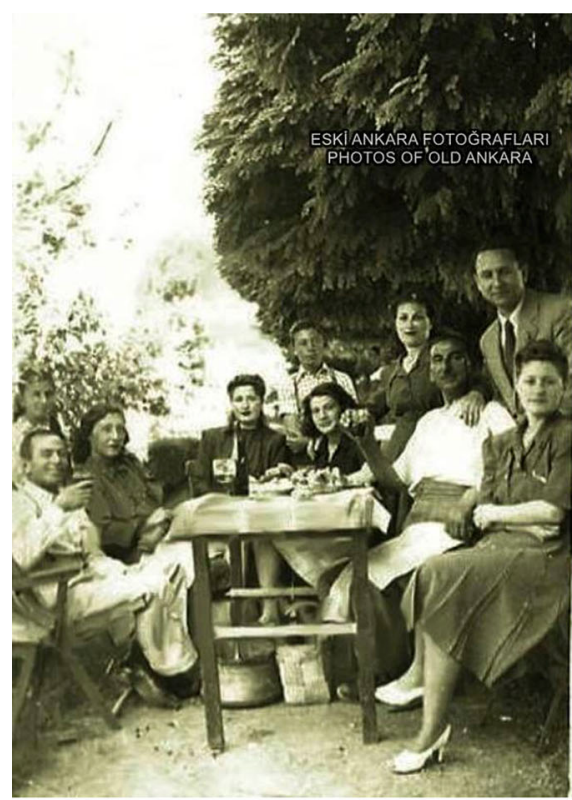

(b)

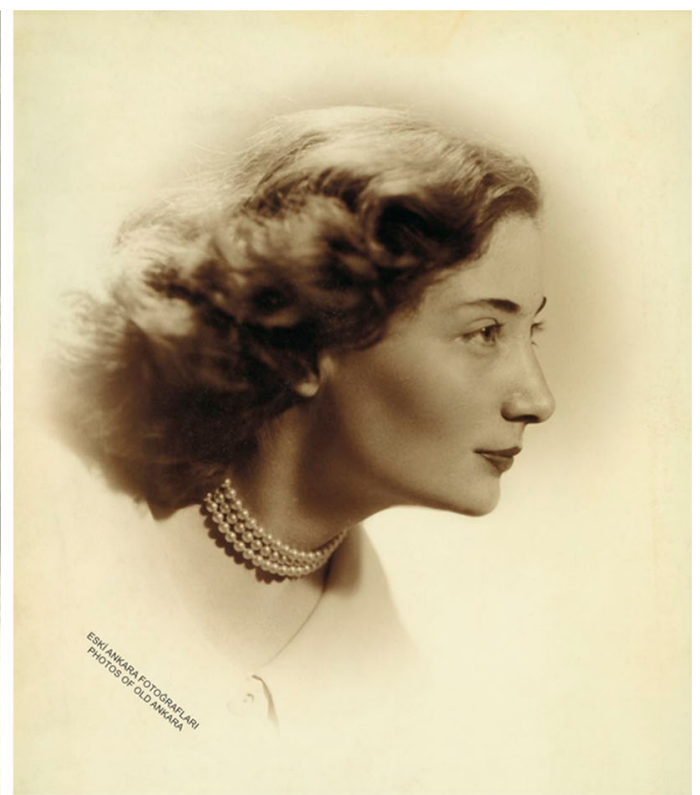

(c)

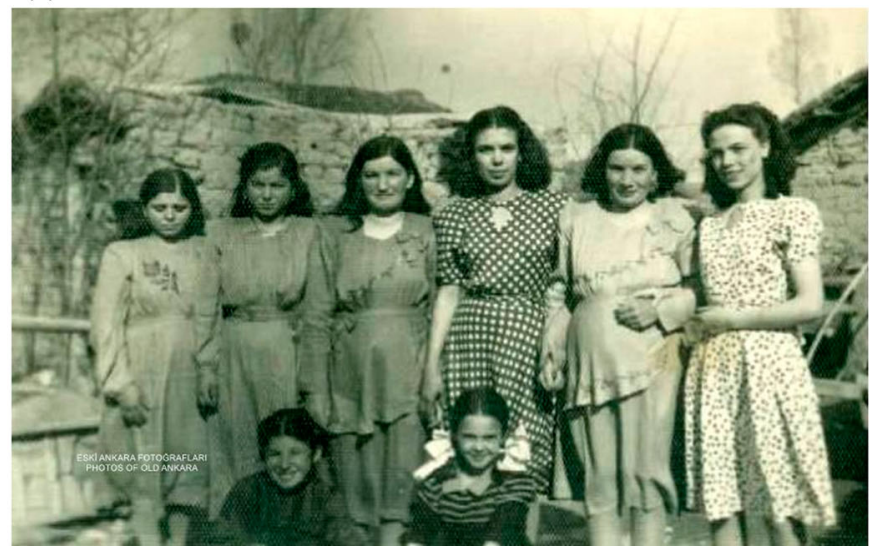

Figure 3. Personal photos posted on photos of old Ankara. With kind permission of photos of old Ankara.

ing visual regime that shaped the image of modern Turkey. Because the Turkish modernization project attributed absolute significance to transforming ways of living, images of the everyday played a vital role in the production and reproduction of a series of dichotomies that have characterized the experience of modernity in Turkey, such as modern/traditional, civilized/ uncivilized and secular/Islamic. For example, during the foundational years of the Republic, the country's new modernity was symbolized by images of the idealized 'Republican woman,' such as women wearing ballroom dresses and young women in shorts, school uniforms, or army uniforms (Deren 2012). It is not unexpected that the photos of urban women in public spaces posted to Facebook groups often prompt nostalgic conversations about the past's modernity and civilization.

This imagination of the modern past in Turkish Facebook communities relates to a broader nostalgia for the foundational years of 
the Republic that emerged in the 1990s, partly in response to the increasing public visibility of Islam and the arrival of a counter-Islamic nostalgia for the Ottoman period (Özyürek 2006). Such nostalgia, Özyürek (2006) argues, has come within a neoliberal transformation of the political field through privatization of state ideology and symbolism, which indicates 'a new kind of relationship citizens have established with the founding principles of the Turkish republic, one that manifests itself in affective, domestic, and otherwise private realms generally considered outside the traditional field of politics' (179; original emphasis). The intense imagination of the modern past, especially in Photos of Old Ankara, is not unexpected, because the Republic's capital and its visual imagery have always been constructed and represented as symbols of a modern way of life (Batuman 2008). Indeed, the early Republican Ankara has emerged as a representation in response to the political conditions of the 1990s, including the rise of political Islam, and has powerfully served in political discourses of nostalgia (Batuman 2008). The group description of Photos of Old Ankara declares Ankara's historical significance as follows:

This group, of which you are now a member, is the first group on nostalgia and urban history of 'old Ankara,' established with the aim of sharing pre- and during-Republic images of our capital city where national decisions were made. ... We should remind you that this is a group on the remarkably meaningful Republican capital, where our Ata [Atatürk] is lying.

Nostalgic conversations in Photos of Old Ankara do not only and simply express bitterness over a lost past, but develop substantial criticism of the present, with constant references to the daily flow of political events. Even unpleasant photos of police interventions in student protests in the 1970s evoke positive responses of 'those difficult days,' compared to the present: 'After seeing today, we have started to hanker after those days,' and 'Back then, at least there was hope for a bright future.'
Nostalgia on Facebook relates to the current desire to preserve and defend the 'Republican memory' against the threat of effacement. For example, a photo was posted of the old Central Restaurant (Figure 4), established in 1925 on Atatürk Orman Çiftliği (Atatürk Forest Farm), and recently transformed into a different eating establishment. A number of comments suggest that the new venue 'especially serves the government party,' and the photo sparked a long nostalgic conversation. In addition to private recollections of 'the taste of artichoke' or 'the wonderful wedding dinner,' experienced there, many group members expressed their frustrations of the loss of a particular memory: 'All the history and memory of this place has been destroyed,' and 'Another symbol and memory of Ankara and the Republic has been ruined.' This photo and many other affectively and politically charged photos have gained new value as visual records of the past, resisting the loss or transformation of public memory.

Boym (2007) argues that nostalgia can be prospective as well as retrospective, because 'the fantasies of the past, determined by the needs of the present, have a direct impact on the realities of the future' (8). For Özyürek (2006), the ongoing public struggle between Kemalist and Islamist politics about readings of the past shows that nostalgia is a 'powerful and versatile way of relating to and transforming the present' (177). Facebook communities focused around nostalgic photos of Turkey intentionally or unintentionally put forth substantial criticism of the present, through a politics of nostalgia that conveys feelings of anxiety about and frustration with the current political conditions. By bridging the emotional with the political, these Facebook communities create 'digital terrains of affective politics' that invite us 'to think about feelings, technologies and politics together, through each other' (Kuntsman 2012).

\section{Conclusion}

As Hoskins (2009) argues, 


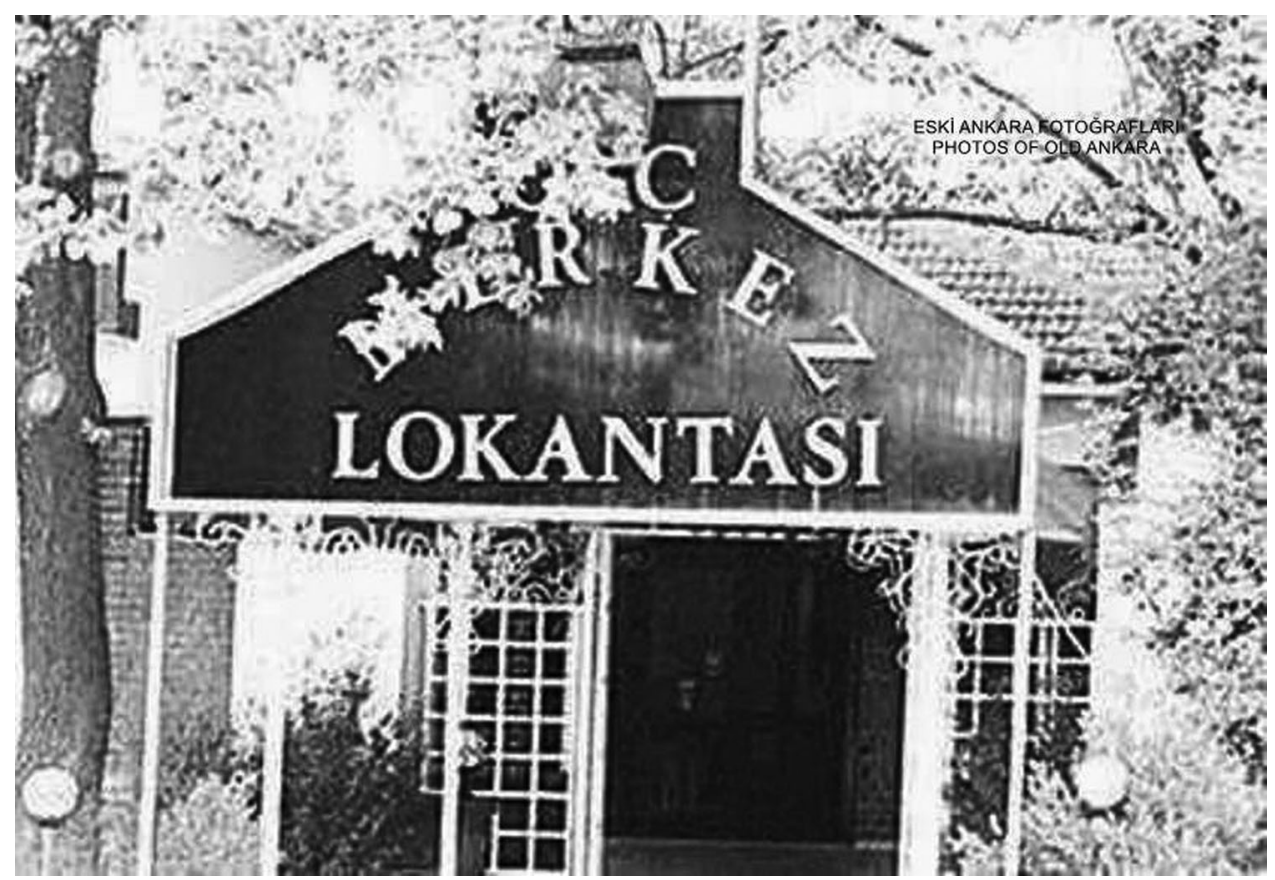

Figure 4. Photo of the old Central Restaurant in Atatürk Forest Farm, posted on photos of old Ankara, with the caption 'Once upon a time ... memory of Atatürk and the republic ....' With kind permission of photos of old Ankara.

memory (individual and collective and their varying intersections) is "mediated" in that how the past is and is not recorded, archived, accessed, retrieved and represented is entangled with the nature, forms and control of the technologies, media and institutions of the day. (27)

The digitally mediated Facebook practices of collecting, archiving, displaying and discussing nostalgic photos of Turkey yield particular forms of knowledge, memory and representations of the past. The participatory and collaborative memory work in Facebook communities gathers private and emotional accounts of the past that are conventionally disregarded by the institutionalized expertise on history. By sharing their personal photos, knowledge, testimonies, narratives and life stories, members of these communities actively and creatively use social media to generate new ways of remembering and representing the past, as well as improving its accessibility and visibility. Furthermore, through exchanging emotionally and politically charged photos and conversations about the past, participants fashion nostalgia as a public feeling that becomes a source for affective political criticism of the present. These practices of remembering and representing the past in Old Photos of Turkey and Photos of Old Ankara demonstrate how the participatory and collaborative social media environment affords new possibilities for enacting creative citizenship.

On the other hand, the creativity of Facebook communities in terms of the potential to generate novel and unconventional representations of the past is subject to a number of limitations. As Bolter and Grusin (2000) argue through the concept of remediation, the new digital media do not externally come to shape a culture, but emerge from within existing cultural contexts that they share with older media. While remediating old photos, the Facebook communities discussed here recycle a pre-existing visual regime that endows everyday images with the 
political power to represent achievements of the Turkish modernization project and often cite national myths circulated by conventionalized representations of the past. Moreover, the political discourses they create about the past and the present represent a limited plurality, because social media communities are usually created through connectivity between people of similar interests and viewpoints (Pogačar 2009).

Even so, the work of remembering and representing the past in Old Photos of Turkey and Photos of Old Ankara cannot be characterized as simply the recycling of older myths with a bittersweet longing for the past; this remembering refashions nostalgia in response to current political conditions. These Facebook communities value old photos of Turkey as visual records that resist the perceived eradication or transformation of a particular public memory by the current political enterprises. Such a value attributed to photos is multiplied by the deliberate act of circulating them in personal Facebook profiles with the aim of informing a larger public. In this manner, Facebook communities about nostalgic photos of Turkey join the dispersed network of political resistance on social media, which is recognized as freer than the increasingly censored media environment in Turkey.

\section{Disclosure statement}

No potential conflict of interest was reported by the authors.

\section{Funding}

This work was supported by 3501 program of The Scientific and Technological Research Council of Turkey (TÜBİTAK) [grant number 115K274].

\section{Notes on contributors}

Özlem Savaş is assistant professor in the Department of Communication and Design at Bilkent University. Her current research project 'Modern practices of self in everyday life: Ethnographic analysis of Facebook as lifestyle media' explores self-reflexive lifestyle practices in the digitally mediated everyday.

\section{References}

Batuman, Bülent. 2008. "Photography at Arms: 'Early Republican Ankara' From NationBuilding to Politics of Nostalgia." METU JFA 2: 99-117.

Bechmann, Anja, and Stine Lomborg. 2013. "Mapping Actor Roles in Social Media: Different Perspectives on Value Creation in Theories of User Participation." New Media \& Society 15: 765-781.

Bolter, J. David, and Richard A. Grusin. 2000. Remediation: Understanding new Media. Cambridge: The MIT Press.

Boym, Svetlana. 2007. "Nostalgia and its Discontents." The Hedgehog Review Summer: 718.

Bruns, Axel. 2008. Blogs, Wikipedia, Second Life, and Beyond: From Production to Produsage. New York: Peter Lang.

Burgess, J. E., M. Foth, and H. G. Klaebe. 2006. "Everyday Creativity as Civic Engagement: A Cultural Citizenship View of New Media." http://eprints.qut.edu.au/5056/1/5056_1.pdf.

Deren, Seçil. 2012. "Kültürel Batılllaşma." In Modern Türkiye'de siyasal düşünce: Modernleșme ve batıcilik, edited by Tanıl Bora and Murat Gültekingil, 382-402. Istanbul: İletişim Yayınları.

Garde-Hansen, Joanne, Andrew Hoskins, and Anna Reading. 2009. "Introduction." In Save as... Digital Memories, edited by Joanne GardeHansen, Andrew Hoskins, and Anna Reading, 1-21. Hampshire: Palgrave Macmillan.

Hargreaves, Ian. 2016. "Are you a Creative Citizen?" In The Creative Citizen Unbound: How Social Media and DIY Culture Contribute to Democracy, Communities and the Creative Economy, edited by Ian Hargreaves and John Hartley, 1-24. Bristol: Policy Press.

Hargreaves, Ian, and John Hartley, eds. 2016. The Creative Citizen Unbound: How Social Media and DIY Culture Contribute to Democracy, Communities and the Creative Economy. Bristol: Policy Press.

Hartley, John. 2010. "Silly Citizenship." Critical Discourse Studies 7: 233-248.

Hartley, John. 2016. "A Problem of KnowledgeSolved?" In The Creative Citizen Unbound: How Social Media and DIY Culture Contribute to Democracy, Communities and the Creative 
Economy, edited by Ian Hargreaves and John Hartley, 1-24. Bristol: Policy Press.

Haskins, E. 2007. "Between Archive and Participation: Public Memory in a Digital age." Rhetoric Society Quarterly 37 (4): 401-422.

Hoskins, Andrew. 2009. "The Mediatisation of Memory." In Save as ... Digital Memories, edited by Joanne Garde-Hansen, Andrew Hoskins, and Anna Reading, 27-43. Hampshire: Palgrave Macmillan.

Jenkins, Henry. 2002. "Interactive Audiences? The Collective Intelligence of Media Fans." In The New Media Book, edited by Dan Harries, 157170. London: British Film Insitute.

Kuntsman, Adi. 2012. "Introduction: Affective Fabrics of Digital Cultures." In Digital Cultures and the Politics of Emotion: Feelings, Affect and Technological Change, edited by Athina Karatzogianni and Adi Kuntsman, 1-17. Hampshire: Palgrave Macmillan.

Lévy, Pierre. 1997. Collective Intelligence: Mankind's Emerging World in Cyberspace. Cambridge: Perseus. McGuigan, J. 2005. "The Cultural Public Sphere." European Journal of Cultural Studies 8 (4): 427443.
Miller, Toby. 2006. Cultural Citizenship: Cosmopolitanism, Consumerism, and Television in a Neoliberal age. Philadelphia, PA: Temple University Press.

Özyürek, Esra. 2006. Nostalgia for the Modern: State Secularism and Everyday Politics in Turkey. Durham: Duke University Press.

Pogačar, Martin. 2009. "(New) Media and Representations of the Past." In Digital Memories: Exploring Critical Issues, edited by Anna Maj and Daniel Riha, 23-30. Oxford: Inter-Disciplinary Press.

Ratto, Matt, and Megan Boler. 2014. DIY Citizenship: Critical Making and Social Media. Cambridge: The MIT Press.

Ryzova, Lucie. 2014. "Nostalgia for the Modern: Archive Fever in Egypt in the age of PostPhotography." In Photographic Archives and the Idea of Nation, edited by Costanza Caraffa and Tiziana Serena, 301-318. Berlin and Munich: De Gruyter.

Uricchio, William. 2004. "Cultural Citizenship in the age of P2P Networks." In Media Cultures in a Changing Europe, edited by Ib Bondebjerg and Peter Golding, 139-164. Bristol: Intellect Press. 